\title{
Dental and medical advertising: comparative analysis of the rules of professional conduct
}

Publicidade odontológica e médica: análise comparativa das normas profissionais

Luciana Vigorito MAGALHÃES 1

(iD) ORCID iD 0000-0002-7827-3207

Tamara Soledad Frontanilla RECALDE'

(iD) ORCID iD 0000-0002-6873-7813

Marcos Vinícius COLTRI²

(iD) ORCID iD 0000-0002-3614-6437

Hermes de Freitas BARBOSA ${ }^{1}$

(i) ORCID ID 0000-0001-7413-5379

Marco Aurelio GUIMARÃES'

(iD) ORCID iD 0000-0001-5377-012X

Ricardo Henrique Alves da SILVA ${ }^{2}$

(iD) ORCID iD 0000-0002-1532-1670

\begin{abstract}
In health care professional activities, advertising is an issue that raises serious discussions and is the cause of some ethical suits in professional entities, since every advertising should follow the provisions of the Code of Professional Responsibility. Therefore, this research study aimed at analyzing, comparing and discussing articles related to advertising and marketing, considering the current regulations from dental and medical entities. In Dentistry, this subject is ruled by the Code of Professional Conduct, Chapter XVI, 'From advertising and marketing'. In Medicine, information is found in two regulations and in several chapters of the Code of Medical Ethics and in Resolution No. 1.974/2011 of the Federal Council of Medicine, which establishes the guiding criteria for medical advertising. The three regulations present articles that refers to participation in mass media, required information in advertisements, use of sensationalism and self-promotion, and publishing of unproven specialties and titles, highlighting the importance of these topics. The medical regulation also includes participation in publishing ads of manufacturing companies and an exclusive committee to deal with advertising and marketing issues, topics that are not considered in the dental regulation.
\end{abstract}

Indexing terms: Forensic Medicine. Health care marketing services. Legal Dentistry.

\section{RESUMO}

Analisar, comparar e discutir os artigos relacionados ao tópico sobre propaganda e publicidade nas legislações vigentes e emanadas das classes odontológica e médica, a partir da consulta a essas legislações. Na Odontologia, este assunto é regido pelo Código de Ética Odontológica, no Capítulo XVI, "Do anúncio, da propaganda e da publicidade". Na Medicina, encontram-se informações em duas legislações sobre o tema, em diversos capítulos do Código de Ética Médica e na Resolução n 1.974/2011 do Conselho Federal de Medicina, que estabelece os critérios norteadores da propaganda médica. As três legislações apresentam artigos que dizem respeito à participação em meios de comunicação em massa, informações mínimas presentes em anúncios, utilização de sensacionalismo e autopromoção e anúncio de especialidades e títulos não comprovados, destacando a importância desses tópicos. A legislação médica traz, também, da participação em anúncios de empresas comerciais relacionadas à sua profissão e sobre uma comissão exclusiva para tratar de assuntos de divulgação, tópicos desconsiderados na legislação odontológica.

Termos de indexação: Medicina legal. Marketing de serviços de saúde. Odontologia legal.

\section{INTRODUCTION}

The Code of Professional Responsibility is a set of rules and moral principles that regulates the activities of a professional entity and, based on it, professionals should take decisions and adopt conducts to carry out his/her job ${ }^{1}$, guaranteeing the standardization of the professional practice to the society ${ }^{2}$.

In this context, a subject that raises great discussion is advertising made by some health care professionals, who should follow the determinations of the Code of Professional Responsibility and has been

\footnotetext{
${ }^{1}$ Universidade de São Paulo, Faculdade de Medicina, Programa de Pós-Graduação em Patologia e Medicina Legal. Av. Bandeirantes, 3900, Monte Alegre, 14049-900, Ribeirão Preto, SP, Brasil. Correspondência para / Correspondence to: LV MAGALHÃES. E-mail: <vigorito.lu@gmail.com>.

${ }^{2}$ Universidade Estadual de Campinas, Faculdade de Odontologia, Programa de Pós-Graduação em Biologia Buco-Dental, área de concentração em Odontologia Legal. Piracicaba, SP, Brasil.

${ }^{3}$ Universidade de São Paulo, Faculdade de Odontologia, Departamento de Saúde Coletiva, Estomatologia e Odontologia Legal. Ribeirão Preto, SP, Brasil. $\boldsymbol{V} \mathbf{v}$

Como citar este artigo / How to cite this article

Magalhães LV, Recalde TSF, Coltri MV, Barbosa HF, Guimarães MA, Silva RHA. Dental and medical advertising: comparative analysis of the rules of professional conduct. RGO, Rev Gaúch Odontol. 2018;66(2):00-00. http://dx.doi.org/10.1590/1981-8637201800020000103472
} 
the cause of some ethical suits by professional bodies ${ }^{3}$. One of the justifications for this would be the excessive number of professionals in the labor market, with a mercantilist practice ${ }^{4}$, advertising not following the respective regulations and aiming at gaining a larger number of patients, but ignoring the legal implications of it. At the same time, patients are increasingly aware of their rights, which makes it necessary for professionals to comply with the rules when advertising ${ }^{5}$.

Failure to comply with these rules may lead to administrative and/or civil conviction, as well as contributing to the devaluation of the profession, showing lack of respect for the society ${ }^{6,7}$. Therefore, the goal of this article is, through documentary research, analyzing, comparing and discussing articles related to advertising and marketing based on the current regulations issued by the dental and the medical institutions.

\section{METHODS}

A comparative analysis was performed considering the current resolutions issued by the dental and the medical institutions that rule advertising in their professions. In Dentistry, this subject is ruled by the Code of Professional Conduct $(\mathrm{CPC})^{8}$, Chapter XVI - 'From advertising and marketing'. And, in Medicine, information is found in two regulations and discussed in several chapters in the Code of Medical Ethics (CME) ${ }^{9}$ and in Resolution No. 1974/2011 of the Federal Council of Medicine $(\mathrm{FCM})^{10}$, which establishes the guiding criteria for medical advertising.

\section{RESULTS}

Table 1 shows the main topics discussed about advertising and in which regulation such topics are addressed by the medical and the dental entities.

Table 1. Additional subjects addressed by the regulations.

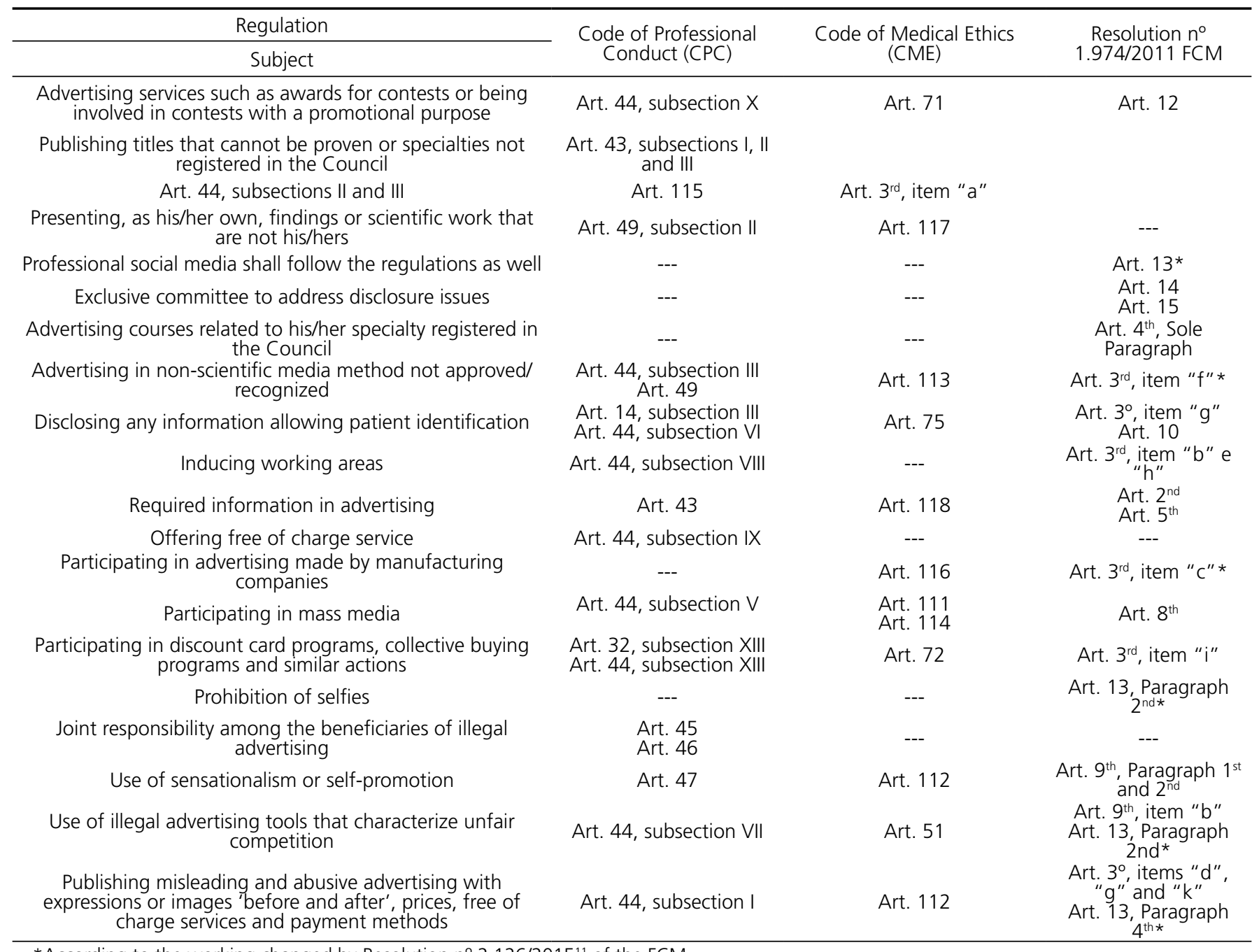

${ }^{*}$ According to the working changed by Resolution $n^{\circ} 2.126 / 2015^{11}$ of the FCM. 


\section{DISCUSSION}

Advertising, as explained by Silva ${ }^{12}$ is one of the most important symbols of the capitalism and the current world. Whenever we turn on the TV, listen to the radio or simply look around, we are faced with advertising. Thus, there is no denying its great influence on the creation of consumers desire. Hence, the need for advertising to be regulated by law.

Medical and dental marketing is part of a relatively recent reality that requires the adjustment of the professional's ethical behaviour ${ }^{13}$. This new reality can be easily seen after verifying the literature, which showed that in 2005 the two most popular media used in dentistry were direct mail and telephone directory ${ }^{14}$. Also, just over five years ago, marketing was still an issue unknown to most medical students ${ }^{13}$.

Between 2000 and 2011, approximately $40 \%$ of the ethical suits instituted against dentists by the Regional Council of Dentistry (RCD) of Espírito Santo ${ }^{15}$ were driven by illegal advertising. In 2012, only $5 \%$ of the open lawsuits referred to illegal medical advertisement in the Regional Council of Medicine (RCM) of São Paulo. This low number occurs because most of the accusations do not progress, because physicians can adjust their conduct and sign a commitment term not to incur the offense ${ }^{13}$ again. In most cases, there are two reasons motivating the conduct, which are the ignorance of the rules or the feeling of impunity.

Professionals are responsible for everything that is informed to others about himself/herself ${ }^{16}$. At this point, it is important to emphasize the need for attention to advertising made by third parties that, direct or indirectly, is relate to the professional, such as practices/offices or health insurance companies to which this professional is accredited. This is because professionals who corroborates with illegal advertising and benefits from it, even if the advertising was not made by him/her, may also incur ethical infraction, as found in several articles of the regulations analysed ${ }^{8-10}$.

Analysing the mentioned ethical rules, it was verified that some basic information should be included in any advertising related to the practice of medical and dental activities. For physicians, it is mandatory to include the name and the registration number in the RCM. And, for dentists, besides the name and the registration number in the RCD, the name of the profession (dental surgeon) should also be in it. In case of advertising of medical legal entities, it shall bear the name of the legal entity, as well as the name and the number of registration in the RCM of the technical manager of the medical legal entity. For dental legal entities, ethical rules require the name of the legal entity, the registration number of the legal entity in the RCD, and the technical manager name and registration number in the RCD. However, in a survey carried out in Maranhão ${ }^{17}$, only $2 \%$ of advertising ads in billboards, signs and banners presented all the required terms.

As in many areas, including health care, the internet has become a revolutionary tool ${ }^{2}$. From a given perspective, we have more informed and critical patients, aware of treatment possibilities, risks, benefits and their rights ${ }^{16}$. And, from another perspective, we have health care professionals, who saw in this tool an additional possibility to approach and gain new patients.

Social networks, due to their great popularity and reach, are among the most used tools in marketing tactics by health care professionals. Lima et al. ${ }^{18}$ investigated the occurrence of ethical infractions in advertising made by dental surgeons and dental practices in professional social networking sites, founding out that more than $85 \%$ of advertisements presented something in disagreement with the $C P C^{8}$. Another survey carried out with medical students showed that a significant number of them believe that they should not worry about the appropriateness of their publications ${ }^{1}$. Thus, it is possible to say that this media is being used improperly, going against what is established by the rules of professional conduct. In an era of technological development, dissemination and sharing of professional information through electronic media should be cautious.

Disclosing and showing treatment images raise some concerns that should be analyzed, such as a potential breach of confidentiality ensured by the regulations. A study showed that it was possible to directly identify patients ${ }^{20}$ in more than $10 \%$ of the images published by dentists and physicians in social network. And, a fact that many professionals are unaware of is that, even if the patient authorizes the use of the image, it can only be used for educational and scientific purposes. It cannot be used as an advertising mean.

In 2015, through Resolution $2.126^{11}$ of the FCM, there was an amendment to the wording of some articles of Resolution 1.974/2011 and, since then, social networking sites of physicians and medical care facilities should also comply with the regulations. A new topic brought by this resolution was the prohibition to publish selfies or selfportraits, a term that does not exist in other regulations. This 
photographic mode, although not mentioned previously, easily fits into other articles of the regulation, primarily due to the prohibition of the disclosure of images that allow the identification of the patient, just as it occurs in selfies. The specific implementation of the term is very positive, as it ceases possible differences in the interpretation of the law. Such confusion is not uncommon, and it can be exemplified by a fact that occurred in the journal of the Regional Council of Dentistry of São Paulo ${ }^{21}$, that published an article saying that dental surgeons could publish selfies.

Another issue in publishing images containing the popular saying 'before and after' is the obligation to achieve similar results in those who have receive the information. Such images call the attention to a result achieved by the professional in another patient, encouraging the individual to seek for similar results, which is not always possible. Such practice is prohibited by the rules of both professional categories 8,10 .

Similarly, the Consumer Protection Code ${ }^{22}$, through Article 30, states that 'any information or advertising, sufficiently precise, conveyed by any means of communication in relation to products and services offered or presented, obliges the supplier who makes it available or uses it and integrates the contract that will be celebrated'. Therefore, supported by the law, any information disclosed in advertising establishes a contract between the publisher and the recipient. Thus, publishing clinical cases and images with treatment results, such as 'before and after, make the professional to take legal commitment to achieve the same result as the image published, since such advertising can make patients to believe that any treatment performed by such professional presents an end result similar to the one adversited7,8,23.

Among the buying modalities that arose with the evolution of consumers behavior, we have the group buying sites. However, such a channel should not be used when it involves health care procedures, mainly because it offers treatment without a previous clinical diagnosis. It was seen that only the $\mathrm{CPC}^{8}$ has specific articles about this type of communication. In a survey analyzing 246 group buying sites, it was found that the most frequently offered dental procedures on these sites were dental whitening, cleaning, dental evaluation and fluoride application ${ }^{25}$. Another important observation to this type of commercialization is that it was also incorporated by Article 53, subsection $\mathrm{XIl}$ of the $\mathrm{CPC}^{8}$, as a severe issue, when it is possible to immediately apply a more severe penalty.

An interesting point verified in Resolution
$1974 / 2011^{10}$ of the FCM are the articles that keep the Medical Affairs Disclosure Committee in the RCM. A specific internal committee aiming at, among other things, assisting professionals with regards to marketing and advertising, explaining and informing the need for adjustments of irregularities, and establishing inquiries ${ }^{10}$. There is not such committee in the dental institutions. As reported by Fernandes et al. ${ }^{3}$, the recurrence of ethical infractions related to advertising is not uncommon. Such behavior clearly exemplifies the fearlessness of professionals towards the belief of impunity over such acts. The establishment of a specialized committee to deal with this issue, responsible for most of the ethical suits in Dentistry, sounds interesting for the professional class, contributing to the effective punishment and correction of the problem, as well as its prevention.

The increasing number of health care professionals entering the labor market and, consequently, the high competitiveness, made professionals to look for ways to attract patients to their offices. However, due to the lack of knowledge or, even, the bad faith of some professionals, fearless of the penalties that this may incur, makes many advertising, in disagreement with the rules, to be shared with the public. This fact can be easily verified by a simple search in the internet, showing several irregular advertising cases $^{20}$.

Health care professionals need to be aware that they do not sell a product. They need to be aware that they work with the health and the well-being of patients, who are unique, with unique need and approach ${ }^{24}$. In addition, the CME, in its fundamental principles, states that Medicine cannot be practiced as a business, thus, the advertising of medical services should be carried out with due respect to the patient's right ${ }^{26}$. Therefore, honest advertising is the gateway to a good relationship between the parties, besides cooperating with the appreciation of the profession ${ }^{27}$.

Finally, it is suggested that a dialogue is established between the two professional entities, through their professional councils, to promote the specific adjustments, standardization and distinctions considering advertising in Dentistry and Medicine.

\section{CONCLUSION}

Thus, by means of this research study, it was possible to analyze, compare and discuss advertising as it is addressed by the current regulations issued 
by dental and medical entities. Comparing both regulations, it was verified that some positive points of a professional entity could be incorporated by the other, aiming at standardizing and reinforcing the trust of the population in both professions, at a time in which there is an increasing number of health care professionals in the market. It is necessary that qualified and ethical professionals are differentiated from those who promote

\section{REFERENCES}

1. Saliba O, Garbin CAS, Garbin AJl, Dossi AP. Responsabilidade do profissional de saúde sobre a notificação de casos de violência doméstica. Rev Saúde Pública. 2007;41(3):472-7. doi: 10.1590/ S0034-89102007000300021

2. Castro EM. A internet como interface na relação médicopaciente: aliada ou inimiga? Arq CRM-PR. 2015;32(126):1-12.

3. Oliveira CML, Bezerra ESM, Lobato IH, Nobre RM, Machado SM, Barroso RF. Processos movidos contra cirurgiões- dentistas no Conselho Regional de Odontologia - seção Pará - nos últimos sete anos. Saúde, Ética \& Justiça. 2010;15(2):46-52.

4. Cavalcanti AL, Ó Silva AL, Santos BF, Azevedo CKR, Xavier AFC. Dentistry and the Consumer Defense Code: analysis of the lawsuits against dentists and dental insurance plans in Campina Grande, PB, Brazil. Rev Odontol UNESP. 2011;40(1):6-11.

5. Fernandes MM, Oliveira MR, Oliveira OF, Paranhos LR, Daruge Júnior E. Veiculação de publicidade irregular relacionada a um cartão de descontos em odontologia: relato de caso. RFO. 2012;17(1):86-90.

6. Miranda GE, Radicchi R, Daruge Júnior E. Análise de websites de cirurgiões-dentistas quanto aos aspectos éticos e legais relativosa à publicidade e propaganda. Rev Bras Odontol. 2013;70(1):804.

7. Miranda SS, Bulcão JA, Almeida C. Propaganda odontológica: avaliação dos aspectos éticos envolvidos. RBOL. 2015;2(1):5367.

8. Conselho Federal de Odontologia (CFO). Resolução CFO n. 118/2012 [Internet]. 2012 [citado em 2017 Jan 11 Jan]. Disponível em: <http://cfo.org.br/wp-content/uploads/2009/09/ codigo_etica.pdf>.

9. Conselho Federal de Medicina (CFM). Resolução CFM n. 1.931/2009 [Internet]. 2009 Set 24 [citado em 2017 Jan 11 Jan]. Disponível em: <http://www.portalmedico.org.br/novocodigo/ integra.asp $>$.

10. Conselho Federal de Medicina (CFM). Resolução CFM n. 1.974/2011 [Internet]. 2011 Ago 19 [citado em 2017 Jan 11 Jan]. Disponível em: <http://www.portalmedico.org.br/ resolucoes/CFM/2011/1974_2011.htm>

11. Conselho Federal de Medicina (CFM). Resolução CFM n. 2.126/2015 [Internet]. 2015 Out 01 [citado em 2017 Out 21]. Disponível em: <https://sistemas.cfm.org.br/normas/arquivos/ resolucoes/BR/2015/2124_2015.pdf>. unfair competition in an increasingly contested labor market.

\section{Collaborators}

LV MAGALHÃES, TSF RECALDE, MV COLTRI, HF BARBOSA, MA GUIMARÃES and RHA SILVA participated in all stages of the preparation of the article.

12. Silva JCL. Publicidade médica e publicidade para médicos: questões éticas e legais. In: XVII Congresso Nacional do CONPEDI. Brasília: CONPEDI; 2008.

13. Alves FHC, Torres FP, Suto HS, Azevedo LSL, Barbosa MM, Pedro RM, et al. Percepções de alunos de medicina sobre marketing médico. Rev Bras Educ Med. 2012;36(3):293-9. doi: 10.1590/ S0100-55022012000500002

14. Serra MC, Garcia PPNS, Dotta EAV, Gonçalves PE. Ferramentas de Marketing empregadas por cirurgiões dentistas. RGO, Rev Gaúch Odontol. 2005;53(2):85-164.

15. Pacheco KTS, Silva Júnior MF, Meireles NR. Ethical proceedings against dentists in Espirito Santo for infringements to the code of dental ethics. Braz Oral Res. 2014;28(1):1-7. Doi: 10.1590/1807-3107BOR-2014.vol28.0002

16. Vaz WL, Reis C. Consentimiento informado na relação medicopaciente. Rev Juríd Cesumar. 2007;7(1):489-514.

17. Martins ALG, Costa MA, Reis MVG, Ladeira LLC, Costa EL, Costa JF. Avaliação dos aspectos éticos da publicidade e propaganda odontológica divulgadas por profissionais em São Luís - MA. Rev Pesq Saúde. 2011;12(2):23-6.

18. Lima AIC, Cruz RA, Silva RA. Análise dos perfis de clínicas odontológicas e de cirurgiões-dentistas em duas redes sociais quanto aos aspectos éticos, de propaganda e publicidade. RBOL. 2016;3(2):66-73.

19. Rocha PN, Castro NAA. Opinions of students from a brazilian medical school regarding online professionalism. J Gen Intern Med. 2014;29(5):758-64. doi: 10.1007/s11606-013-2748-y

20. Martorell LB, Nascimento WF, Garrafa V. Redes sociais, privacidade, confidencialidade e ética: A exposição de imagens de pacientes no facebook. Interface. 2016;20(56):13-23. doi: 10.1590/1807-57622014.0902

21. Revista do CROSP. Doutor, vamos fazer uma selfie? 2017;6:71-2 [citado em 2017 Jan 11]. Disponível em: <http://www.crosp.org. br/uploads/publicacoes/fb551f3dd3ccb4de26ddfe3c135ffe31. pdf>.

22. Brasil. Lei n. 8.078, de 11 de setembro de 1990. Dispõe sobre a proteção do consumidor e dá outras providências [Internet] [citado em 2017 Jan 11]. Disponível em: <http://www.planalto. gov.br/ccivil_03/leis//8078.htm>

23. Machado MA, Daruge E, Paranhos LR. Estratégias de comunicação e o código de ética odontológica. Rev Clín Ortod Dent Press. 2013;12(2):72-6. 
24. Silva RHA. Orientação profissional para o cirurgião-dentista: ética e legislação. São Paulo: Santos; 2010.

25. Oliveira WHT, Prado MM, Silva RF. Publicidade odontológica na internet: os sites de compra coletiva. RBOL. 2014;1(1):78-91.

26. Conselho Federal de Medicina (CFM). Código define limites de divulgação médica. Jornal Medicina. 2010;185:6-7 [citado em 2017 Jan 11]. Disponível em: <http://www.flip3d.com.br/web/ temp_site/edicao-a223c6b3710f85df22e9377d6c4f7553.pdf>.
27. Paranhos LR, Benedicto EN, Fernandes MM, Viotto FRS, Daruge Júnior E. Implicações éticas e legais do marketing na Odontologia. RSBO. 2011;8(2):219-24.

Received on: 31/7/2017

Final version resubmitted on: 30/10/2017

Approved on: 21/11/2017 